\title{
Antiplasmodial activity and genome mining study of marine-derived Streptomyces sp. GMY01
}

\author{
Ema Damayanti ${ }^{1,2}$, Jaka Widada ${ }^{3^{*}}$, Achmad Dinoto ${ }^{4}$, Mustofa ${ }^{5}$ \\ ${ }^{1}$ Doctoral Program of Biotechnology, Graduate School of Universitas Gadjah Mada, Yogyakarta, \\ ${ }^{2}$ Research Division for Natural Product Technology, Indonesian Institute of Sciences, Yogyakarta, \\ ${ }^{3}$ Department of Agricultural Microbiology, Faculty of Agriculture, Universitas Gadjah Mada, \\ Yogyakarta, ${ }^{4}$ Research Center for Biology, Indonesian Institute of Sciences, Cibinong, ${ }^{5}$ Department \\ of Pharmacology and Therapy, Faculty of Medicine, Public Health and Nursing, Universitas \\ Gadjah Mada, Yogyakarta, Indonesia
}

https://doi.org/10.22146/ijpther.1335

\begin{abstract}
Submitted: $16 / 02 / 2021$
Accepted : dd/mm/2021

High resistance to chloroquine in most malaria-endemic area in the world

\section{Keywords:}

Actinobacteria; antiplasmodial; genome analysis; marine Streptomyces;

leads to the need for new antimalaria drugs. Marine bacterium Streptomyces is the source for potential new antimalarial molecules. This research aimed to investigate antiplasmodial activity of marine-derived of Streptomyces sp. GMY01 and to identify potential active compounds using genome mining study. In vitro antiplasmodial activity assays using flow cytometry method showed that the ethyl acetate extract of this bacterium had high antiplasmodial activity (IC $\mathrm{C}_{50}$ value of $1.183 \mu \mathrm{g} / \mathrm{mL}$ ) on Plasmodium falciparum FCR3. Genome mining analysis of wholegenome sequences using antiSMASH 6.0 beta version revealed that Streptomyces sp. GMY01 had 28 biosynthetic gene clusters (BGCs), including the genes encoding polyketide synthase, non-ribosomal peptide synthetase, terpene, lanthipeptide, bacteriocin, butyrolactone, ectoin, siderophore, and others. The known BGCs were predicted to be involved in the production of known compounds from gene clusters ranged from 5 to 100\% similarity. Ongoing purification and elucidation of the structures will allow identification of the active compounds produced by marine-derived Streptomyces sp. GMY01.
\end{abstract}

\begin{abstract}
ABSTRAK
Tingginya tingkat resistensi terhadap klorokuin di hampir semua daerah endemik malaria di dunia mendorong perlunya obat antimalaria baru. Bakteri laut Streptomyces merupakan sumber molekul antimalaria baru yang potensial. Penelitian ini bertujuan untuk mengkaji aktivitas antiplasmodial bakteri asal laut Streptomyces sp. GMY01 dan mengidentifikasi senyawa aktif potensial menggunakan studi genome mining. Uji antiplasmodial in vitro dengan metode flow cytometry menunjukkan ekstrak etil asetat bakteri ini memiliki aktivitas antiplasmodial tinggi $\left(\mathrm{IC}_{50}=1,183 \mu \mathrm{g} / \mathrm{mL}\right)$ pada Plasmodium falciparum FCR3. Analisis genome mining sekuen genom menyeluruh menggunakan antiSMASH 6.0 versi beta menunjukkan bahwa Streptomyces sp. GMY01 memiliki 28 gen kluster biosintesis yang mengkode poliketida sintase, non-ribosomal peptide sintetase, terpene, lanthipeptide, bacteriocin, butirolactone, ectoin, siderophore, dan lainnya. Gen kluster biosintesis yang telah diketahui diprediksi berperan dalam produksi senyawa-senyawa yang telah diketahui dengan similaritas $5-100 \%$. Purifikasi senyawa dan elusidasi struktur sedang dilakukan akan mengidentifikasi senyawa aktif yang dihasilkan bakteri asal laut Streptomyces sp. GMY01.
\end{abstract}




\section{INTRODUCTION}

Malaria is an infectious disease caused by Plasmodium that is transmitted through the bite of a female Anopheles mosquito. ${ }^{1}$ Malariaremainsamajorhealth problem worldwide due to resistance to currently available antimalarial drugs especially chloroquine. The drugs resistance caused malarial treatment failure in almost all malaria endemic areas. ${ }^{2}$ Therefore, the World Health Organization has recommended artemisinin-based combination therapies (ACT) as first-line drugs to replace sulfadoxine-pyrimethamine and chloroquine in the treatment of malaria. However, recent studies have reported cases of artemisinin resistance to $P$. falciparum in Southeast Asia. ${ }^{3,4}$ The emergence and spread of drug-resistant Plasmodium species possibly trigger the re-emergence of malaria outbreaks, thereby encouraging efforts to discover and develop new drugs. ${ }^{5,6}$

Previous studies revealed new antiplasmodial compounds isolated from Streptomyces bacteria., ${ }^{7,8}$ Streptomyces bacteria have been the main source of commercial drug and antibiotic candidates for decades. ${ }^{9,10}$ Streptomyces has provided bioactive molecules for more than 10,000 of the 18,000 known bacterial bioactive compounds. Streptomyces have a linear chromosome with an extremely large genome size (between 6.2 and 12.7 Mb); approximately $5 \%$ of the genome is responsible for the synthesis of secondary metabolites. ${ }^{11}$

The potential biotechnology of Streptomyces species can be revealed through genome mining techniques, where biosynthetic gene clusters (BGCs) can be identified and can be used to predict the chemical core structures of molecules. ${ }^{10}$ Streptomyces contain the largest number of BGCs, such as the gene encoding polyketide synthetase (PKS), non-ribosomal peptide synthetases (NRPSs), or PKS-NRPS hybrids. ${ }^{11}$ Over the last 10 years, several new active compounds from streptomyces have been revealed through genome mining approaches ${ }^{12,13}$
In the previously study, Streptomyces sp. GMY01 from the marine sediment in Krakal Beach, Yogyakarta, Indonesia was successfully isolated and identified. ${ }^{14}$ The biological assay of GMY01 extract exhibited anticancer activity against the breast cancer celllines MCF7 and T47D. ${ }^{15,16}$ However, the active compounds detected from GMY01 have not been identified and their antiplasmodial activity have not been investigated. This study aimed to investigate antiplasmodial activity of Streptomyces sp. GMY01 extract and to identify of potential active compound using genome mining study.

\section{MATERIALS AND METHODS}

\section{Biological material}

Streptomyces sp. GMY01 was deposited at the Indonesian Culture Collection (WDCM 769), Indonesian Institute of Sciences (LIPI) as InaCC A147 and NITE Biological Research Center (NBRC, WDCM 825) Japan with registration number NBRC 110111. Human Plasmodium falciparum FCR3 was obtained from the Eijkman Institute for Molecular Biology, Jakarta, Indonesia.

\section{Fermentation and extraction}

Streptomyces sp. GMY01 was maintained in ISP-2 agar medium (Difco, Sparks, USA). Then, Streptomyces sp. GMY01 was cultured at $28{ }^{\circ} \mathrm{C}$ with 180 rpm agitation for 3 days in a $250 \mathrm{~mL}$ Erlenmeyer flask containing $100 \mathrm{~mL}$ tryptic soy broth (Difco, Sparks, USA) as the seed medium. Then, the cells were transferred into four $1000 \mathrm{~mL}$ flasks containing $500 \mathrm{~mL}$ starch nitrate broth (SNB) as the production medium and incubated for 11 days at $28{ }^{\circ} \mathrm{C}$ with 180 rpm agitation in a shaking incubator. The SNB medium contained $0.5 \mathrm{~g} \mathrm{NaCl}, 1$ $\mathrm{g} \mathrm{KNO}_{3}, 0.5 \mathrm{~g} \mathrm{~K}_{2} \mathrm{HPO}_{4}, 0.5 \mathrm{~g} \mathrm{MgSO}_{4} \cdot 7 \mathrm{H}_{2} \mathrm{O}$, $0.01 \mathrm{~g} \mathrm{FeSO}_{4} \cdot 7 \mathrm{H}_{2} \mathrm{O}$, and $20 \mathrm{~g}$ starch in $1000 \mathrm{~mL}$ distilled water. Secondary metabolites were obtained by separating the cell biomass from the liquid using refrigerated centrifugation at $4137 \times \mathrm{g}$ at $4{ }^{\circ} \mathrm{C}$ for $15 \mathrm{~min}$. The supernatant was extracted two times with an equal volume of ethyl acetate and evaporated to obtain 
the crude extract. The all chemical reagents and solvents were purchased from Merck KGaA, Darmstadt, Germany.

\section{Antiplasmodial assay using flow cytometry}

Plasmodium falciparum FCR-3 was cultured in accordance with the previous method with minor modifications. ${ }^{17}$ The cultures were maintained in $2 \%$ fresh human erythrocytes (red blood cells, RBCs) (O+, male) suspended in Roswell Park Memorial Institute (RPMI) 1640 (Gibco, Thermo Fisher Scientific, USA) containing $10 \%$ human serum $\left(\mathrm{O}^{+}\right.$, male) and $500 \mu \mathrm{g}$ gentamicin (Indofarma, Bekasi, Indonesia) per liter. The flasks were incubated at $37{ }^{\circ} \mathrm{C}$ under a gas mixture of $5 \% \mathrm{O}_{2}$ and $5 \% \mathrm{CO}_{2}$. Every 3-4 days, the infected erythrocytes were transferred to a fresh complete medium with uninfected erythrocytes. The stock culture was synchronized with 5\% sorbitol as described by Lambros and Vanderberg. ${ }^{18}$ For the antiplasmodial assay, the extract was prepared by adding $0.1 \%$ dimethyl sulfoxide (DMSO) (Sigma-Aldrich) (w/v) at various concentrations $(0.25-8 \mu \mathrm{g} / \mathrm{mL})$. The Plasmodium growth inhibition assay was performed in a total volume of 200 $\mu \mathrm{L}$ using 96-well microplates (Iwaki), with each plate containing a $100 \mu \mathrm{L}$ extract solution and $100 \mu \mathrm{L}$ Plasmodium inoculum at the parasitemia level of 5\% in a $5 \% \mathrm{CO}_{2}$ incubator (CellXpert $\mathrm{C} 170 \mathrm{i}$, Eppendorf AG, Hamburg, Germany) at 37 ${ }^{\circ} \mathrm{C}$ for $3 \times 24 \mathrm{~h}$ of incubation. Plasmodium growth was observed by making thin blood film preparations with Giemsa stain (Merck, Germany) for microscopic observation (Nikon YS100 biological microscope, Japan). Flow cytometry analysis was carried out by SYBR Green I stain in accordance with the work of Rebelo with minor modifications. ${ }^{19}$ The extract solution and chloroquine as a control at various concentrations were used as the treatments. For each measurement, $200 \mu \mathrm{L}$ Plasmodium culture (approximately $1.8 \times 10^{11} \mathrm{RBCs}$ ) was centrifuged to separate the cells from the medium. Ten microliters of cells were stained with $1 \mu \mathrm{L}$ DNA-specific dye SYBR Green I ( $1 \times$ the concentration)
(Invitrogen, Carlsbad, USA) and $10 \mu \mathrm{L}$ CD235a antibody (eBioscience, San Diego, USA). After 10 min of incubation in the dark, the stained sample was immediately analyzed by flow cytometry using a 535/45 $\mathrm{nm}$ bandpass filter in front of the detector (BD FACS Calibur flow cytometer, USA). The results of flow cytometric analysis were analyzed using CellQuest software. The RBCs in uninfected and infected samples were detected by their characteristic forward and side scatter properties. Staining with the anti-glycophorin CD235 antibody was used to establish that all events detected represented RBCs. The percent Plasmodium inhibition was obtained by formula:

$$
\% \text { inhibition }=\frac{\mathrm{A}-\mathrm{B}}{\mathrm{A}} \times 100
$$

A: SYBR Green I fluorescens intensity in control (RPMI medium)

B: SYBR Green I fluorescens intensity in treatment

The half maximal inhibitory concentration $\left(\mathrm{IC}_{50}\right.$ ) values of the extracts were obtained using regression analysis of $\log _{10}$ concentrations of the extract against percent Plasmodium inhibition. This analysis was performed using Graph Pad Prism 9.

The protocol of the study was approved by the Medical and Health Research Ethic Committee, the Faculty of Medicine, Public Health and Nursing, Universitas Gadjah Mada, Yogyakarta (ref. no. KE/FK/0279/EC/2019).

\section{Genome mining analysis}

The whole-genome sequence of Streptomyces sp. GMY01 was determined by next-generation sequencing platforms using 454 pyrosequencing technology (454 GS FLX) and HiSeq1000 (Illumina) as published in a previous study.15 In this study, the identification gene clusters involved in the biosynthesis of secondary metabolites and predictions of the core structures produced were conducted by using antiSMASH 6.0 beta version,20 which is available at http:// antismash.secondarymetabolites.org. 
Accession number(s): This wholegenome shotgun project has been depositedatData BankofJapan/European Nucleotide Archive/GenBank under the accession number JABBNA000000000. The version described in this paper is version JABBNA010000000.

\section{RESULTS}

From the supernatant of $10 \mathrm{~L}$ of 11 days old cultured in liquid SNB medium,
792 mg crude ethyl acetate extract was obtained from the supernatant. The antiplasmodial assay using flow cytometry analysis showed that the crude extract of GMY01 inhibited $P$. falciparum FCR3 growth. The $\mathrm{IC}_{50}$ value of the crude ethyl acetate from the supernatant was $1.183 \mu \mathrm{g} / \mathrm{mL}$ whereas $\mathrm{IC}_{50}$ value of chloroquine was 1.820 $\mu \mathrm{g} / \mathrm{mL}$ (FIGURE 1). The low $\mathrm{IC}_{50}$ of the GMY01 extract indicates its potential as an antiplasmodial.

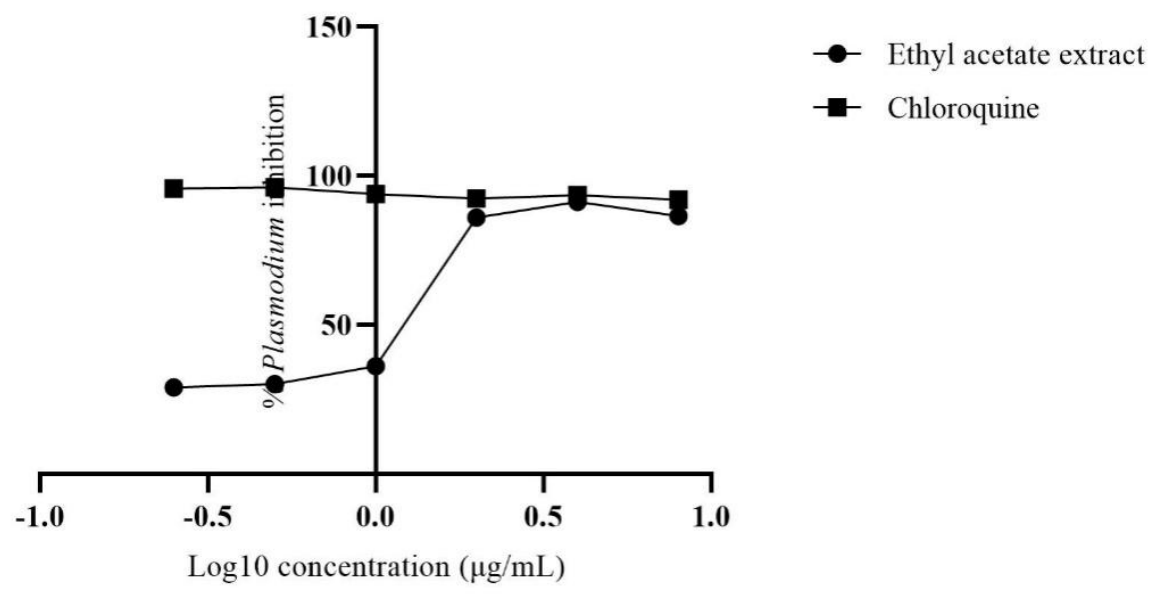

FIGURE 1. Plasmodium falciparum FCR3 inhibition by ethyl acetate extract of Streptomyces sp. GMY01 and chloroquine at various concentrations

Fluorescens intensity of SYBR Green I show the number of Plasmodium parasite that infected RBC. The intensity of the SYBR Green I fluorescence was calculated based on the gated percent value of the total events in the upper right region. the upper right was the positive region of the SYBR green I antibody (infected $\mathrm{RBC}$ ) and was the positive region of the CD235a antibody (total RBC). The results of flow cytometry analysis in FIGURE 2 shows that extract treatment (2 $\mu \mathrm{g} / \mathrm{mL})$ (FIGURE 2.a) has low fluorescens intensity of SYBR Green I compared with the controls (infected RBC without drug) (FIGURE 2.c), and it was similar with chloroquine treatment $(2 \mu \mathrm{g} / \mathrm{mL})$ as a commercial antimalarial (FIGURE 2.b). FIGURE 4.d shows very low fluorescens intensity of SYBR Green I in uninfected RBC (uninfected RBC). This indicated that SYBR Green I was selective stain for genetic material (DNA) of Plasmodium. 

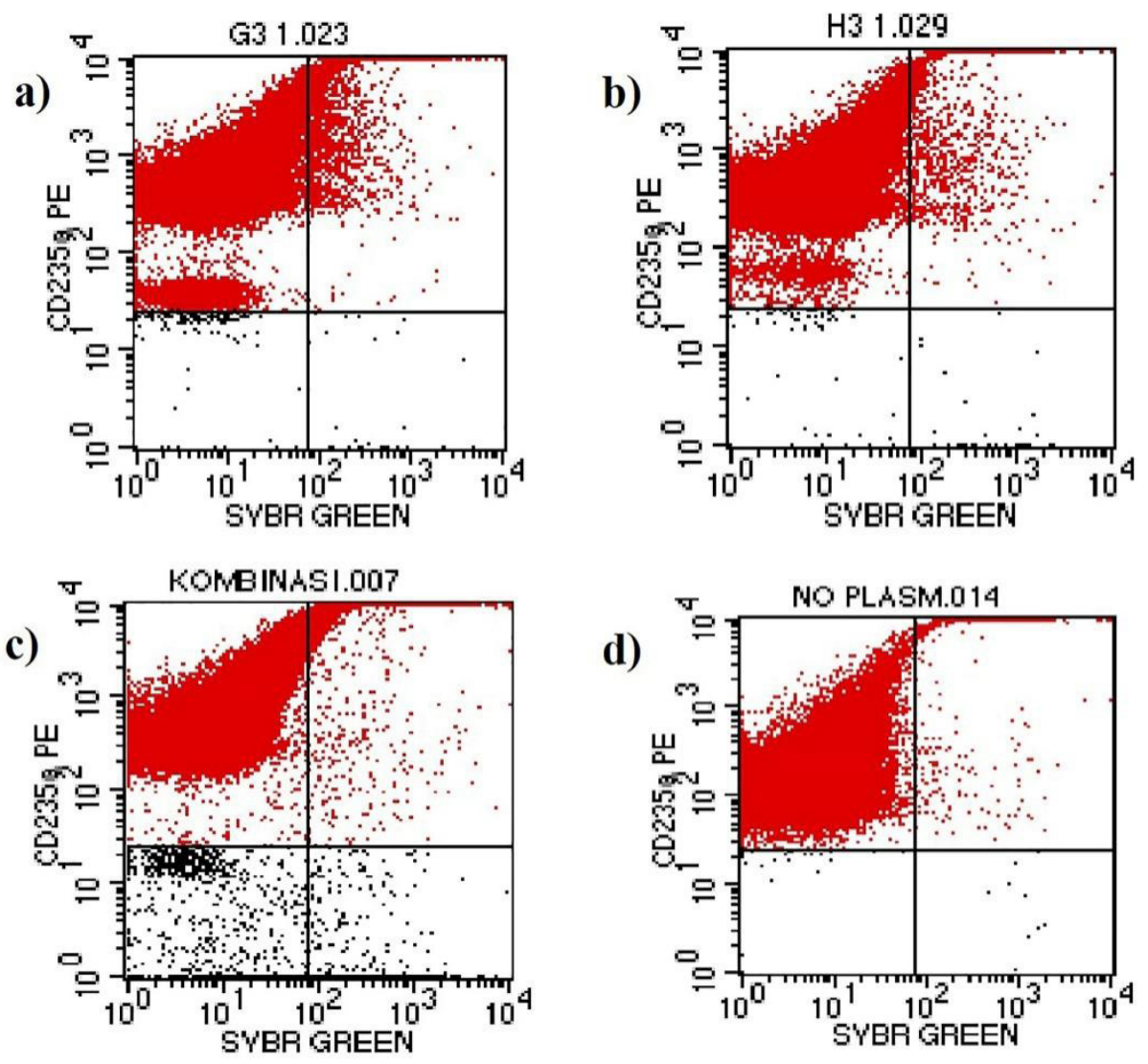

FIGURE 2. Flow cytometry analysis using SYBR Green I stain for Plasmodium DNA intensity and CD235a for red blood cells (RBC) intensity. Plasmodium falciparum FCR-3 growth on $2 \mu \mathrm{g} / \mathrm{mL}$ ethyl acetate extract of Streptomyces sp. GMY01 (a), $2 \mu \mathrm{g} / \mathrm{mL}$ chloroquine (b), the positive control (infected RBC without drug) (c), the negative control (uninfected $\mathrm{RBC})(\mathrm{d})$.

The genome mining analysis of the whole-genome sequence of GMY01 using antiSMASH 6.0 revealed the 28 regions consisting of 23 known regions and 5 unknown regions, which encoding NRPS modules, PKS, terpene, ectoin, lanthipeptide, siderophore, butyrolactone, and others (TABLE 1). Genes encoding NRPS and PKS types were dominant in the BGC analysis. The BGCs were predicted to be involved in the production of putative secondary metabolite such as geosmin, ectoine and albaflavenone with $100 \%$ deduced amino acid sequence similarities; microansamycin, deimino-antipain, venezuelin, mirubactin, scabichelin, hopene, abyssomicins M-X and spore pigments with $\geq 50 \%$ similarity; and lysocin, herboxidiene, stenothricin, saframycin A/B, streptobactin, S56-p1, grincamycin, scleric acid, isorenieratene, saframycin A, vazabitide A and informatipeptine with $\leq 50 \%$ similarity. 
TABLE 1. Genome mining analysis of the Streptomyces sp. GMY01 genome using antiSMASH 6 beta version

\begin{tabular}{|c|c|c|c|c|c|}
\hline Region & $\begin{array}{l}\text { Biosynthesis Gene } \\
\text { Cluster (BGC) Type }\end{array}$ & $\begin{array}{l}\text { Most similar } \\
\text { known cluster }\end{array}$ & Similarity (\%) & Length (bp) & Origin Organism \\
\hline 4.1 & NRPS & No matches found & - & - & - \\
\hline 13.1 & $\begin{array}{l}\text { NRPS, Lanthipeptide } \\
\text { class ii }\end{array}$ & Lysocin & 9 & 71,777 & Lysobacter sp. RH2180-5 \\
\hline 21.1 & Type 3 PKS (T3PKS) & Herboxidiene & 6 & 159,472 & $\begin{array}{l}\text { Streptomyces } \\
\text { chromofuscus }\end{array}$ \\
\hline 21.2 & NRPS, NAPAA & Stenothricin & 13 & 54,895 & S. roseosporus \\
\hline 23.1 & NRPS & Saframycin A/B & 12 & 62,804 & S. lavendulae \\
\hline 24.1 & Terpene & Geosmin & 100 & 2,181 & S. coelicolor \\
\hline 24.2 & RiPP like, NRPS & Streptobactin & 47 & 26,478 & $\begin{array}{l}\text { Streptomyces sp. ATCC } \\
700974\end{array}$ \\
\hline 24.3 & $\begin{array}{l}\text { Type } 1 \text { PKS (T1PKS), } \\
\text { NRPS-like, NRPS, } \\
\text { Butyrolactone, } \\
\text { REE-containing }\end{array}$ & Microansamycin & 67 & 69,750 & $\begin{array}{l}\text { Micromonospora sp. } \\
\text { HK160111 }\end{array}$ \\
\hline 24.4 & Siderophore & No matches found & - & - & - \\
\hline 25.1 & Ectoin & Ectoine & 100 & 3,366 & S. anulatus \\
\hline 26.1 & NRPS & Deimino-antipain & 66 & 15,484 & S. albulus \\
\hline 27.1 & $\begin{array}{l}\text { Lanthipeptide class } \\
\text { iv }\end{array}$ & Venezuelin & 50 & 5,339 & S. venezuelae. \\
\hline 27.2 & RiPP-like & No matches found & - & - & - \\
\hline 27.3 & NRPS, other & S56-p1 & 17 & 67,922 & $\begin{array}{l}\text { Streptomyces sp. } \\
\text { SoC090715LN-17 }\end{array}$ \\
\hline 28.1 & NRPS & Mirubactin & 50 & 27,717 & Actinosynnema mirum \\
\hline 29.1 & T1PKS, NRPS & Scabichelin & 90 & 30,020 & S. scabies \\
\hline 30.1 & $\begin{array}{l}\text { Lanthipeptide class } \\
\text { iv }\end{array}$ & No matches found & - & - & - \\
\hline 36.1 & Terpene & Albaflavenone & 100 & 2,468 & S. coelicolor A3(2) \\
\hline 38.1 & Siderophore & Grincamycin & 5 & 41,909 & S. lusitanus \\
\hline 42.1 & Butyrolactone & Scleric acid & 23 & 18,478 & S. sclerotialus \\
\hline 45.1 & Terpene & Isorenieratene & 15 & 9,777 & S. argillaceus \\
\hline 48.1 & NRPS & Saframycin A & 12 & 62,804 & S. lavendulae \\
\hline 49.1 & Terpene & Hopene & 53 & 13,757 & S. coelicolor A3(2) \\
\hline 53.1 & T1PKS, hgIE-KS & Vazabitide A & 17 & 40,455 & S. sp. SANK 60404 \\
\hline 53.2 & $\begin{array}{l}\text { Bacteriocin, Lanthi- } \\
\text { peptide }\end{array}$ & Informatipeptin & 8 & 14,866 & $\begin{array}{l}\text { S. viridochromogenes } \\
\text { DSM } 40736\end{array}$ \\
\hline 55.1 & Butyrolactone & No matches found & - & - & \\
\hline 60.1 & T1PKS & Abyssomicins M-X & 56 & 70,308 & Streptomyces sp. LC-6-2 \\
\hline 63.1 & Type 2 PKS (T2PKS) & Spore pigment & 83 & 11118 & S. avermitilis \\
\hline
\end{tabular}

NRPS: Non-ribosomal peptide synthetase; PKS: Polyketide synthase; NAPAA: non-alpha poly-amino acids; RiPP: ribosomally synthesised and post-translationally modified peptide

\section{DISCUSSION}

Streptomyces sp. GMY01 displayed strong activity against $P$. falciparum
FCR-3 using flow cytometry analysis. SYBR Green I could be applied for antiplasmodial assays because the dye specifically colors Plasmodium DNA. ${ }^{19}$ 
High fluorescens intensity of SYBR Green I indicate high levels of parasitemia. Conversely, low SYBR Green I fluorescens intensity indicate Plasmodium inhibition.

The $\mathrm{IC}_{50}$ values of the antiplasmodials in this study were almost the same as those in other research, such as the active compounds of Streptomyces BCC26924 with $\mathrm{IC}_{50}$ values against $P$. falciparum $\mathrm{K} 1$ between 0.24 and $>10 \mu \mathrm{g} / \mathrm{mL}^{8}{ }^{8}$ Isaka $^{7}$ revealed that the metacycloprodigiosin compounds, namely, bafilomycin A and spectinabilin from Streptomyces spectabilis BCC 4785, obtained 0.005-7.8 $\mu \mathrm{g} / \mathrm{mL} \mathrm{IC}_{50}$ against $P$. falciparum $\mathrm{K} 1$.

The antiplasmodial activity produced by Streptomyces GMY01 was suggested to be related to its anticancer activity. The results of this study were similar to those of a previous research. The ethyl acetate extract of GMY01 had anticancer activity against human breast cancer cells, with IC $_{50}$ values of $19 \mu \mathrm{g} / \mathrm{mL}$ in T47D cells and $7 \mu \mathrm{g} / \mathrm{mL}$ in MCF7 cells. ${ }^{14}$ Other studies reported that the anticancer compound SB939 inhibit $P$. falciparum at all cycles in either the asexual or exoerythrocytic phase and cerebral malaria caused by P. berghei. ${ }^{6}$ In addition, the antimalarial compound artemisinin and its analogs show anticancer activity and have synergistic effect with available anticancer drugs without increasing the toxicity to normal cells. ${ }^{21,22}$ This result was consistent with the hypothesis that anticancer compounds could be antiplasmodial.

Whole-genome sequence analysis showed that Streptomyces sp. GMY01 is closely related to Streptomyces albus J1074. ${ }^{15}$ Genome mining analysis using antiSMASH 6.0 showed that Streptomyces sp. GMY01 has a large group of NRPSand PKS-encoded secondary metabolites. These results indicate that the marine origin of Streptomyces has high potential to be developed as a large source of active compound. However, compared with others marine Streptomyces, which has almost the same genome size, the BGCs in GMY01 are less than those in Streptomyces MP131-18. ${ }^{23}$

Biological activities of putative secondary metabolite based on genome mining study showed in TABLE 2 . Most of the compounds predicted to be produced by Streptomyces sp. GMY01 has biological activities as antimicrobial, antibiotic, and antitumor - anticancer.

TABLE 2. Biological activities of putative secondary metabolites resulted by Streptomyces sp. GMY01 based on genome mining study

\begin{tabular}{ll}
\multicolumn{1}{c}{$\begin{array}{c}\text { Most similar known } \\
\text { cluster }\end{array}$} & \multicolumn{1}{c}{ Biological activity } \\
\hline Lysocin & Antibiotic ${ }^{24}$ \\
Herboxidiene & Anti-cholesterol ${ }^{25}$ \\
Stenothricin & Antibiotic ${ }^{26}$ \\
Saframycin A/B & Antibiotic antitumor ${ }^{27}$ \\
Geosmin & Earthy smelling substance ${ }^{28}$ \\
Streptobactin & A new catechol-type siderophore ${ }^{29}$ \\
Microansamycin & Antiproliferative ${ }^{30}$ \\
Ectoine & Natural cell protectant ${ }^{31}$ \\
Deimino-antipain & Peptidic protease inhibitor ${ }^{32}$ \\
Venezuelin & unknown \\
S56-p1 & unknown \\
Mirubactin & Siderophore \\
Scabichelin & Siderophore \\
\hline
\end{tabular}




\begin{tabular}{ll}
\hline Albaflavenone & Antibiotic $^{35}$ \\
Grincamycin & Antitumor - anticancer ${ }^{36}$ \\
Scleric acid & Anti-Mycobacterium ${ }^{37}$ \\
Isorenieratene & Antioxidant ${ }^{38}$ \\
Saframycin A & Antitumor ${ }^{39,40}$ \\
Hopene & unknown \\
Vazabitide A & Immunosuppressive effect ${ }^{41}$ \\
Informatipeptin & unknown \\
Abyssomicins M-X & Antimicrobial, antitumor, anti- \\
& Mycobacteria, anti-HIV \\
Spore pigment & unknown \\
\hline
\end{tabular}

In previous studies, it was known that antibiotic and anticancer compounds had the ability as antiplasmodial. Nocathiacins are a thiazolyl peptide group of antibiotics which have the ability to inhibit $P$. falciparum in vitro. ${ }^{43}$ Tetracyclines, macrolides, quinolones, and rifampin also demonstrated in vitro activity against $P$. falciparum ${ }^{44}$ An anticancer, novobiocinferrocene conjugates display moderate anticancer against the MDA-MB-231 breast cancer line and promising antiplasmodial against $P$. falciparum 3D7 strain. ${ }^{45}$ In the other hand, several antiplasmodial also have activity as anticancer such as primaquine homodimers which have antiplasmodial activities on $P$. berghei and $P$. falciparum and anticancer activities on three cancer cell lines (MCF-7, HCT116, H 460). ${ }^{46}$ Three classes of antimalarial drugs are well-established and experimental: artemisinin, synthetic peroxide and DHFR (dihydrofolate reductase) inhibitors show inhibition of proliferation in human cancer cells. ${ }^{47}$

This research has contributed to antiplasmodial discovery as candidates for antimalarial drugs from bacteria, especially Streptomyces. Bacteria that are known to produce anticancer and antimicrobial metabolites also have the potential to produce antiplasmodial. This study will accelerate the discovery of alternative antimalarial compounds.

\section{CONCLUSION}

Marine-derived bacteria Streptomyces sp. GMY01, previously known to have anticancer activity, also known to have high antiplasmodial activity. Genome mining analysis of the whole genome sequence shows that this bacterium produces putative compounds from secondary metabolites. These putative compounds are known to have some antimicrobial, antibiotic, anticancer and, antitumor activity. Further study would be conducted to isolate the active antiplasmodial compound from the Streptomyces sp. GMY01.

\section{ACKNOWLEDGEMENTS}

This research was funded by Indonesian Ministry for Research, Technology and Higher Education under Doctoral Dissertation Research program (Project Number: 3121/UN1.DITLIT/DITLIT/PT/2020). Authors would like to thank Farid Abdullah for technical supervision on flow cytometry analysis.

\section{REFERENCES}

1. Rodríguez JV, Mena RP, CrespoLladó KN, Ortiz J, Ferrer-Rodríguez I, Serrano AE. Implications of glutathione levels in the Plasmodium berghei response to chloroquine and artemisinin. PLoS One 2015;10: 1-15. https://doi.org/10.1371/journal. pone.0128212

2. Harinantenaina Rakotondraibe L, Rasolomampianina R, Park HY, Li J, Slebodnik C, Brodie PJ, et al. Antiproliferative and antiplasmodial compounds from selected Streptomyces species. Bioorganic Med Chem Lett 2015; 25:5646-9. 
ht tps://doi.org/10.1016/j. bmcl.2015.07.103

3. Antony HA, Parija SC. Antimalarial drug resistance: An overview, 2016. Trop Parasitol 2016; 6(1):30-41. https://doi.org/10.4103/2229-5070.175081

4. Vale N, Aguiar L, Gomes P. Antimicrobial peptides: a new class of antimalarial drugs? Front. Pharmacol 2014; 5: 275. https://doi.org/10.3389/fphar.2014.00275

5. Cui L, Miao J, Cui L. Cytotoxic effect of curcumin on malaria parasite Plasmodium falciparum: inhibition of histone acetylation and generation of reactive oxygen species. Antimicrob. Agents Chemother 2007; 51: 488-94. https://doi.org/10.1128/AAC.01238-06

6. Sumanadasa SDM, Goodman CD, Lucke AJ, Skinner-Adams T, Saham I, Haque A, et al. Antimalarial activity of the anticancer histone deacetylase inhibitor SB939. Antimicrob. Agents Chemother 2012; 56: 3849-56. https://doi.org/10.1128/AAC.00030-12

7. Isaka M, Jaturapat A, Kramyu J, Tanticharoen M, Thebtaranonth Y. Potent in vitro antimalarial activity of metacycloprodigiosin isolated from Streptomyces spectabilis BCC 4785. Antimicrob Agents Chemother 2002 Apr; 46(4): 1112-3.

h t t p s://d o i . org/10.1128/ AAC.46.4.1112-1113.2002

8. Intaraudom C, Bunbamrung $\mathrm{N}$, Dramae A, Danwisetkanjana K, Rachtawee P, Pittayakhajonwut P. Antimalarial and antimycobacterial agents from Streptomyces sp. BCC27095. Tetrahedron Lett 2015; 56: 6875-7.

https://doi.org/10.1016/j. tetlet.2015.10.098

9. Choi SS, Kim HJ, Lee HS, Kim P, Kim ES. Genome mining of rare actinomycetes and cryptic pathway awakening. Process Biochemistry 2015; 50:1184-93.

h t tps://d oi.org/10.1016/j. procbio.2015.04.008

10. Weber T, Charusanti P, Musiol-Kroll EM, Jiang X, Tong Y, Kim HU, et al. Metabolic engineering of antibiotic factories: New tools for antibiotic production in actinomycetes. Trends Biotechnol 2015; 33: 15-26.

h t tps://doi.org/10.1016/j . tibtech.2014.10.009

11. Undabarrena A, Ugalde JA, Seeger M, Cámara B. Genomic data mining of the marine actinobacteria Streptomyces sp. H-KF8 unveils insights into multistress related genes and metabolic pathways involved in antimicrobial synthesis. PeerJ 2017; 5: e2912.

https://doi.org/10.7717/peerj.2912

12. Schneider O, Simic N, Aachmann FL, Rückert C, Kristiansen KA, Kalinowski J, Jiang Y, Wang L, Jiang C-L, Lale R, Zotchev SB. Genome mining of streptomyces sp. Yim 130001 isolated from lichen affords new thiopeptide antibiotic. Front Microbiol 2018; 9: 1-12.

https://doi.org/10.3389/fmicb.2018.03139

13. $\mathrm{Xu} \mathrm{XN}$, Chen LY, Chen $\mathrm{C}$, Tang YJ, Bai FW, Su C, Zhao XQ. Genome mining of the marine actinomycete Streptomyces sp. DUT11 and discovery of tunicamycins as anticomplement agents. Front Microbiol 2018; 9: 1-16.

https://doi.org/10.3389/fmicb.2018.01318

14. Farida Y, Widada J, Meiyanto E. Combination methods for screening marine actinomycetes producing potential compounds as anticancer. Indones J Biotechnol 2007;12: 988-97.

15. Herdini C, Hartanto S, Mubarika $\mathrm{S}$, Hariwiyanto B, Wijayanti N, Hosoyama A, et al. Diversity of nonribosomal peptide synthetase genes in the anticancer producing actinomycetes isolated from marine sediment in indonesia. Indones J Biotechnol 2015; 20: 34.

https://doi.org/10.22146/ijbiotech.15266

16. Werdyani S, Wijayanti N, Fitria A, Rahmawati S. Cytotoxic effects of ethyl acetate fractions from secondary metabolites of Streptomyces Sp. GMY01 on human breast cancer MCF7 cell lines. Asian J Pharm Clin Res 2017;10: 9-11.

h t t p s://doi.org/10.22159/ ajpcr.2017v10s3.21351

17. Trager W, Jensen JB. Human malaria parasites in continuous culture. 
Science 1976 Aug 20;193(4254):673-5. https://doi.org/10.1126/science.781840

18. Lambros C, Vanderberg JP. Synchronization of Plasmodium falciparum erythrocytic stages in culture. J Parasitol 1979; 65(3):41820.

https://doi.org/10.2307/3280287

19. Rebelo M, Sousa C, Shapiro HM, Mota MM, Grobusch MP, Hänscheid T. A novel flow cytometric hemozoin detection assay for real-time sensitivity testing of Plasmodium falciparum. PLoS One 2013 Apr 24; 8(4):e61606.

https://doi.org/10.1371/journal. pone.0061606

20. Blin K, Shaw S, Steinke K, Villebro R, Ziemert N, Lee SY, et al. AntiSMASH 5.0: Updates to the secondary metabolite genome mining pipeline. Nucleic Acids Res 2019; 47(W1):W81-7.

https://doi.org/10.1093/nar/gkz310

21. Sanz LM, Crespo B, De-Cózar C, Ding XC, Llergo JL, Burrows JN, GarcíaBustos JF, Gamo FJ. Plasmodium falciparum in vitro killing rates allow to discriminate between different antimalarial mode-of-action. PLoS One 2012; 7(2):e30949.

https://doi.org/10.1371/journal. pone.0030949

22. Das A. Anticancer effect of antimalarial artemisinin compounds. Ann Med Health Sci Res 2015; 5(2):93-102.

https://doi.org/10.4103/2141-9248.153609

23. Paulus C, Rebets Y, Tokovenko B, Nadmid S, Terekhova LP, Myronovskyi $\mathrm{M}$, et al. New natural products identified by combined genomics-metabolomics profiling of marine Streptomyces sp. MP131-18. Sci Rep 2017; 7:1-11.

https://doi.org/10.1038/srep42382

24. Hamamoto $H$, Urai $M$, Ishii $K$, Yasukawa J, Paudel A, Murai M, et al. Lysocin e is a new antibiotic that targets menaquinone in the bacterial membrane. Nat Chem Biol 2015; 11(2):127-33.

https://doi.org/10.1038/nchembio.1710

25. Shao L, Zi J, Zeng J, Zhan J. Identification of the herboxidiene biosynthetic gene cluster in Streptomyces chromofuscus ATCC 49982. Appl Environ Microbiol 2012; 78:2034-8.

https://doi.org/10.1128/AEM.06904-11

26. Kappner M, Hasenböhler A, Zähner H. Stoffwechselprodukte von mikroorganismen. Arch Microbiol 1977 Dec 15; 115(3):323-31. https://doi.org/10.1007/BF00446459

27. Li L, Deng W, Song J, Ding W, Zhao QF, Peng C, et al. Characterization of the saframycin a gene cluster from Streptomyces lavendulae NRRL 11002 revealing a nonribosomal peptide synthetase system for assembling the unusual tetrapeptidyl skeleton in an iterative manner. J Bacteriol 2008; 190(1):251-63.

https://doi.org/10.1128/JB.00826-07

28. Gerber NN, Lechevalier HA. Geosmin, an earthy-smelling substance isolated from Actinomycetes. Appl Microbiol 1965; 13(6):935-8.

h t t p s://d o i.org / 10.1128 / AEM.13.6.935-938.1965

29. Matsuo Y, Kanoh K, Jang JH, Adachi K, Matsuda S, Miki O, et al. Streptobactin, a tricatechol-type siderophore from marine-derived streptomyces sp. YM5-799. J Nat Prod 2011; 74(11):2371-6. https://doi.org/10.1021/np200290j

30. Wei F, Wang Z, Lu C, Li Y, Zhu J, Wang $\mathrm{H}$, et al. Targeted discovery of pentaketide ansamycin aminoansamycins A-G. Org Lett 2019; 21(19):7818-7822.

https://doi.org/10.1021/acs . orglett.9b02804

31. Graf R, Anzali S, Buenger J, Pfluecker F, Driller $\mathrm{H}$. The multifunctional role of ectoine as a natural cell protectant. Clin Dermatol 2008; 26(4):326-33.

h t tps://doi.org/10.1016/j . clindermatol.2008.01.002

32. Maxson T, Tietz JI, Hudson GA, Guo XR, Tai HC, Mitchell DA. Targeting reactive carbonyls for identifying natural products and their biosynthetic origins. J Am Chem Soc 2016 23;138(46):15157-15166. https://doi.org/10.1021/jacs.6b06848

33. Giessen TW, Franke KB, Knappe TA, Kraas FI, Bosello M, Xie X, et 
al. Isolation, structure elucidation, and biosynthesis of an unusual hydroxamic acid ester-containing siderophore from actinosynnema mirum. J Nat Prod 2012; 75(5):905-14. https://doi.org/10.1021/np300046k

34. Kodani S, Bicz J, Song L, Deeth RJ, Ohnishi-Kameyama M, Yoshida M, et al. Structure and biosynthesis of scabichelin, a novel trishydroxamate siderophore produced by the plant pathogen Streptomyces scabies 87.22. Org Biomol Chem 2013; 11(28):4686-94. https://doi.org/10.1039/c3ob40536b

35. Lin $X$, Cane DE. Biosynthesis of the sesquiterpene antibiotic albaflavenone in streptomyces coelicolor. mechanism and stereochemistry of the enzymatic formation of epi-isozizaene. J Am Chem Soc 2009; 131(18):6332-3. https://doi.org/10.1021/ja901313v

36. Lai Z, Yu J, Ling H, Song Y, Yuan J, Ju $\mathrm{J}$, et al. Grincamycins i-k, cytotoxic angucycline glycosides derived from marine-derived actinomycete Streptomyces lusitanus SCSIO LR32. Planta Med 2018; 84(3):201-207. https://doi.org/10.1055/s-0043-119888

37. Alberti F, Leng DJ, Wilkening I, Song L, Tosin M, Corre C. Triggering the expression of a silent gene cluster from genetically intractable bacteria results in scleric acid discovery. Chem Sci 2018; 10(2):453-463. https://doi.org/10.1039/C8SC03814G

38. Baskar V, Madhanraj P, Kanimozhi K, Panneerselvam A. Characterization of carotenoids from Streptomyces sp. of marine and fresh water environment. Arch Appl Sci Res 2010; 2(6):380-8.

39. Kishi K, Yazawa K, Takahashi K, Mikami Y, Arai T. Structure-activity relationships of saframycins. J Antibiot (Tokyo) 1984; 37(8):847-52. https://doi.org/10.7164/antibiotics.37.847

40. Kaneda S, Hour-Young C, Yazawa K, Takahashi K, Mikami Y, Arai T. Antitumor activity of new semisynthetic saframycin derivatives. Jpn J Cancer Res 1986; 77(10):1043-9.

41. Yashiro T, Sakata F, Sekimoto T,
Shirai T, Hasebe F, Matsuda K, et al. Immunosuppressive effect of a non-proteinogenic amino acid from Streptomyces through inhibiting allogeneic $\mathrm{T}$ cell proliferation. Biosci Biotechnol Biochem 2019; 83(6):1111-6.

https://doi.org/10.1080/09168451.201 9.1591262

42. Sadaka C, Ellsworth E, Hansen PR, Ewin R, Damborg P, Watts JL. Review on abyssomicins: inhibitors of the chorismate pathway and folate biosynthesis. Molecules 2018; 23(6):1371.

h t t p s://doi.org/10.3390/ molecules23061371

43. Sharma I, Sullivan M, McCutchan TF. In vitro antimalarial activity of novel semisynthetic nocathiacin I antibiotics. Antimicrob Agents Chemother 2015; 59(6):3174-9.

https://doi.org/10.1128/AAC.04294-14

44. Pradines B, Rogier C, Fusai T, Mosnier J, Daries W, Barret E, et al. In vitro activities of antibiotics against Plasmodium falciparum are inhibited by iron. Antimicrob Agents Chemother 2001; 45(6):1746-50.

h t t p s://d o i.org / 10.1128 / AAC.45.6.1746-1750.2001

45. Mbaba M, de la Mare JA, Sterrenberg JN, Kajewole D, Maharaj S, Edkins $\mathrm{AL}$, et al. Novobiocin-ferrocene conjugates possessing anticancer and antiplasmodial activity independent of HSP90 inhibition. J Biol Inorg Chem 2019; 24(2):139-149. https://doi.org/10.1007/s00775-0181634-9

46. Pavić K, Rubinić B, Rajić Z, Fontinha $\mathrm{D}$, Prudêncio $\mathrm{M}$, Uzelac $\mathrm{L}$, et al. Primaquine homodimers as potential antiplasmodial and anticancer agents. Bioorganic Med Chem Lett 2019; 29(19):126614.

h t t p s://d oi .org/ $10.1016 /$ j . bmcl.2019.08.018

47. Van Huijsduijnen RH, Guy RK, Chibale K, Haynes RK, Peitz I, Kelter $\mathrm{G}$, et al. Anticancer properties of distinct antimalarial drug classes. PLoS One 2013; 8(12):e82962.

https://doi.org/10.1371/journal. pone.0082962 